doi: $10.19090 /$ i.2017.28.171-188

UDC: 741.5(091)"'1945/1947"

ÁGNES TAMÁS

University of Szeged, Department of Modern Hungarian History

tagnes83@yahoo.com

\title{
OLD-NEW ENEMIES IN HUNGARIAN AND YUGOSLAV CARICATURES AFTER THE SECOND WORLD WAR (1945-1947)
}

\begin{abstract}
In this paper I analyse caricatures of Hungarian and Yugoslav comic papers (Jež, Ludas Matyi, Új Szó, and Pesti Izé) between 1945 and 1947. I chose this source since the analysis of caricatures can demonstrate the functioning of communist propaganda. After the presentation of sources and goals of the paper, I analyse the depiction of war criminals, the perception of democracy and the Western states, and the representation of democrats and German enemies within the country in Hungary. Then I analyse the depiction of the self of the communists and finally, before the conclusions, the Peace Treaty of Paris in caricatures. The analysed propaganda caricatures documented well the views and propaganda methods of the Communist Parties regarding the abovementioned topics.
\end{abstract}

Keywords: Caricatures, Hungarian and Yugoslav comic papers, depiction of the enemy, propaganda.

\section{Sources and goals}

$\mathrm{T}$

The Second World War ended about 70 years ago and the Paris Peace Treaty with the defeated Eastern European countries was signed in 1947. The brief period between these two events was characterized by the changes both in Eastern and Western Europe, which determined the outlook of the continent for decades, making it worth analysing them in caricatures, too. These three years were the period of parliamentary pluralism in Hungary, but the Communist Party gradually came into power. In Hungary 1948 was the turning point; in Yugoslavia communists were already in power in 1945. This short period was freer in Hungary than the strict censorship of WWII, and also freer than the subsequent communist era. This was a dynamic period with a lot of changes in order to develop socialist societies in both states, therefore it is worth comparing the caricatures of Hungarian and Yugoslav comic papers from these years. Politically eventful epochs offer generally a more interesting analysis of comic papers. Although the Communist Party controlled the press - through the rationing of paper-new comic papers appeared in 
Hungary and the new comic papers reflected the views of the various (re-)organized parties, but Ludas Matyi, Hungary's communist comic paper appeared in a much higher number of copies than the others. ${ }^{1}$ The comic papers were popular readings, both adults and children could be influenced and "taught" by this way of communist propaganda. In this paper I analyse only the propaganda function of caricatures.

To compare the results of the analysis, I examine the Yugoslav communist comic paper, Jež. Both in Hungary and in Yugoslavia the comic papers had had long traditions and in both countries comic papers appeared after WWII as well, which motivated the choice of the compared journals. Jež appeared with the title Ošišani jež before and during WWII (1935-1941), too. Table 1 presents the names of the analysed comic papers or newspaper, the years and places of publication, and, finally, the party affiliations of the comic papers. Both Jež and Ludas Matyi declared that they would follow the policy of the Soviet communist comic paper Crocodile and $U_{j}^{\prime}$ Szó adopted caricatures from this comic paper published in Moscow.

\begin{tabular}{|l|l|l|l||}
\hline $\begin{array}{l}\text { Name of } \\
\text { the comic paper }\end{array}$ & $\begin{array}{l}\text { Years of } \\
\text { publication }\end{array}$ & $\begin{array}{l}\text { Place of } \\
\text { publication }\end{array}$ & Party affiliation \\
\hline $\begin{array}{l}\text { Pesti Izé } \\
\text { ('Pest whatchamacallit') }\end{array}$ & $\begin{array}{l}\text { November } \\
1946-1947\end{array}$ & Budapest & $\begin{array}{l}\text { No unambiguous party connection, the } \\
\text { redactor belonged to the Social Democrat } \\
\text { Party, similar to Ludas Matyi. }\end{array}$ \\
\hline $\begin{array}{l}\boldsymbol{U} \boldsymbol{j} \text { Szó } \\
\text { ('New Word') }\end{array}$ & $\begin{array}{l}\text { February } \\
1945-1947\end{array}$ & Budapest & $\begin{array}{l}\text { The newspaper of the Soviet Red Army for } \\
\text { the Hungarian population which contained } \\
\text { caricatures, too. } \\
\text { Soviet Communist Party }\end{array}$ \\
\hline $\begin{array}{l}\text { Ludas Matyi } \\
\text { ('Mattie the Goose-Boy') }\end{array}$ & $\begin{array}{l}\text { May } \\
1945-1947\end{array}$ & Budapest & Communist Party of Hungary \\
\hline $\begin{array}{l}\text { Ježz } \\
\text { ('Hedgehog') }\end{array}$ & $\begin{array}{l}\text { October } \\
1945-1947\end{array}$ & Belgrade & Communist Party of Yugoslavia \\
\hline
\end{tabular}

Table 1: The analysed sources

Using the method of historical comparison, ${ }^{2}$ I address the following issues: first, I will analyse how the extreme right political groups and war criminals were depicted in the two countries, Yugoslavia and Hungary. The extreme right groups could appear as "new enemies", as evil Others after the end of the censorship of right wing governments in the communist comic papers. Another important question illustrating the functioning of propaganda is who was depicted as a war criminal and which groups were made into the new enemies so that they were presented as war criminals in the communist comic papers. These representations of the new enemy of communist parties had the aim to influence the opinion of the readers about the criticized groups (e. g. clergy or Western states). The communists were "old enemies" in these countries, they were persecuted between the two world wars and during WWII. Therefore, it is an interesting question how the depiction of the communists changed after WWII and, in turn, how the depiction of workers changed.

\footnotetext{
${ }^{1}$ Horváth 2013: 19.

${ }^{2}$ See Kaelble 1999.
} 
Finally, I will analyse if the Hungarian comic papers depicted the winners as evil Others, too, or only the extreme right groups and the Germans, who were held responsible for the war. After WWI the winner states appeared as enemies, for example, depicted as devils, because the losing states - including Hungary - made them and the farther small entente states responsible for the Paris Peace Treaty in 1920 considered unjust by them. ${ }^{3}$ Thus, it is worth analysing the depiction of the Western states and the new Peace Treaty of Paris (February 1947) in the communist comic papers as well.

\section{War criminals in caricatures}

After the end of military events, the public demanded the conviction of people who were responsible for war crimes and crimes against humanity during WWII. The leaders were tried and convicted and after a few months in prison they were sentenced to death. In the Yugoslav comic paper, the leader of the Serbian right wing puppet state, Milan Nedić, appeared at first in prison. ${ }^{4}$ However, the Chetnik and Ustaše soldiers and leaders were depicted much more frequently than Nedić, since Nedić committed suicide in 1946. The comic papers represented current political events and after his death, the propaganda against Nedić lost its topicality. The Chetniks and Ustaše came up together regularly, therefore the ethnical and ideological differences between the two groups became irrelevant, both groups were defined collectively as war criminals. Draža Mihailović was a commander of an anticommunist monarchist movement and the Minister of war of Yugoslavian exiled Government, accused of collaboration with Nazis. In contrast, the Ustaša was a Croatian fascist movement establishing the Independent State of Croatia with the leadership of Ante Pavelić. ${ }^{5}$ The leader of the Ustaša, Ante Pavelić was not depicted in caricatures, because he was able to escape from Yugoslavia. Thus, one can observe only an advertisement demanding his extradition. In the picture, one can see a skull with a bloody dagger. ${ }^{6}$ In contrast, the Chetnik leader appeared often in prison, so in one of the caricatures with the title "Draža Mihailović and his troops are marching in Belgrade" ironically he is walking into prison alone. ${ }^{7}$ Both the Chetnik and Ustaše soldiers were depicted with out-of-date weapons - which is dishonourable in their case - with a dagger, often bloody, which is symbolic of disingenuous attacks and of unfair combat. In contrast, in case of the Yugoslav communist soldiers it is an honour that partisans could defeat the enemy with non-modern weapons.

In the Hungarian comic papers former regent Miklós Horthy (in office: 1920-1944) appeared as a war criminal who was held responsible for the participation of Hungary in WWII in spite of the fact that he was not sentenced in the Nuremberg Trials (or in Hungary). Horthy was not imprisoned, thus he cannot be seen in prison in the caricatures, but, first, his facial features were disfigured to a great extent and he was depicted as a witch or devil as

\footnotetext{
${ }^{3}$ See Tamás 2015.

${ }^{4}$ Jež, 12 January 1946.

${ }^{5}$ Ramet 2011: 185.

${ }^{6}$ Jež, 4 May 1946.

${ }^{7}$ Jež, 30 March 1946.
} 
well. ${ }^{8}$ Ferenc Szálasi, the "Leader of the Nation", ${ }^{9}$ was depicted similarly to the Serbian Chetnik leader and like him he can be seen in jail, dreaming about his release. ${ }^{10}$ War criminals were depicted in prison-in Jež more often than in the Hungarian comic papersbecause the cartoonists could demonstrate not only the responsibility of the war criminals but also the power of the new states with these scenes: the enemies of the new regimes will be imprisoned and they will be called to account for their sins. In contrast, Új Szó, reflecting the perspective of Soviet propaganda, was not satisfied with the "speed" of the Hungarian jurisdiction. In one caricature the Roman goddess of justice Justitia is traveling on the back of a turtle whose hind legs have lead balls attached to them to slow the animal down even further. ${ }^{11}$

In connection with the topic of war criminals two common motifs appeared often and were visually very similar in the Hungarian and Yugoslav caricatures. On the one hand, the caricaturists depicted them in hell, with Adolf Hitler, Benito Mussolini, Hermann Göring, Joachim von Ribbentrop and Szálasi burning in it. ${ }^{12}$ The message of these scenes is always the same: these ideologists, military or political leaders arrived where they belong and their penalty is justified and well-earned. On the other hand, the motif of ghosts appeared more than once, either haunting war criminals in a prison, or the war criminals being the ghosts themselves. In Jež Mihailović is haunted by ghosts in gas masks, and-not very heroically - he hides under his bed. Szálasi appears to Hungarian politicians evoking originally Horthy, but according to Szálasi "He cannot come yet, because he is still alive." It is unlikely that the comic paper wanted to suggest the ignorance of those invoking the ghost, rather it communicated the dissatisfaction of Ludas Matyi that Horthy was not accused of war crimes. ${ }^{13}$

A similar feature of Ludas Matyi and Jež was that these comic papers began a campaign against Roman Catholic prelates. According to the communist ideology church was seen as an enemy, thus the propaganda was necessary against the church. ${ }^{14}$ In Hungary it campaigned against the archbishop of Esztergom, József Mindszenty, in Yugoslavia against the archbishop of Zagreb, Alojzije Stepinac. ${ }^{15}$ Moreover, the caricatures connected the whole Roman Catholic Church — from the pope to the lowest monk-with extreme right organisations in order to represent them as war criminals, in order to represent them as part of the old regime and not part of the new people's democracies. I have to note that some Croatian Franciscan monks served the Ustaša, but they were dismissed from the monastic order. The most well-known Franciscan former monk, Tomislav Filipović, was the head of the Croatian concentration camp in Jasenovac. ${ }^{16}$ In caricatures priesthood appeared as

\footnotetext{
${ }^{8}$ Ludas Matyi, 2 June 1946, Ludas Matyi, 2 December 1945.

9 The Hungarian translation of the German word 'Führer', Hungarian prime minister (1944-1945). He was executed in 1946.

${ }^{10}$ Ludas Matyi, 20 January 1946, Jež, 29 June 1946.

${ }^{11}$ Új Szó, 5 July 1945.

${ }^{12}$ Ludas Matyi, 20 October 1946, Új Szó, 23 May 1946, Jež, 25 January 1947, Pesti Izé, 23 November 1947.

${ }_{13}$ Jež, 1 June 1946, Ludas Matyi, 21 March 1947.

${ }^{14}$ The persecution of priesthood happened earlier in the Soviet Union as well.

${ }^{15}$ József Mindszenty was not a war criminal, about the role of Stepinac see Ramet 2011:182-183.

${ }^{16}$ Ramet 2011: 176.
} 
unhelpful to the poor people - contrary to their oath — but they lived well behind the thick walls, which is signed textually with captions and visually with the clerics being overweight. They are accused in the caricatures of supporting the Ustaša and the Hungarian fascists, of participating in the deportation of Jews, and of the killing of Jews. In many cases they wear swastikas or arrow crosses, the symbol of Hungarian fascists, or letter $U$, the symbol of the Ustaša, which suggests that they agreed with the ideology as well, that they were not only observers but also part of the organisations. ${ }^{17}$ The caricatures generalized the blame against priesthood, always depicting a monastery or church, as well as Nazi collaborates in all cases. The special feature of these caricatures was the anonymity, except for the archbishops who were recognizable, which made the clergy collectively guilty. Out of the numerous examples I want to mention a caricature in which Stepinac wears a necklace with the symbols of the Nazis and Ustaša, ${ }^{18}$ or another one in which he is standing near skulls and burning houses (Fig. 1). The caricature with the title "A fish rots from the head down" indicates also the role of the leaders of the Catholic Church. In the caricature one can observe a fish with a clerical cap on, and next to the fish there is a crook, hand weapons, Ustaša symbols, money, other valuables and dentures. ${ }^{19}$ In another caricature clerics are working in the archives of the cathedral of Zagreb. The clerics are putting valuables, jewels and dentures on the shelves, on which the names of concentration camps (Jasenovac, Jadovno, Gradiška) are written (Fig. 2). The caption of the caricature suggests that clerics took part in different acts of cruelty earlier as well, because one of them states that "I always loved the archiving activities." While Stepinac was sentenced in 1946, the Hungarian caricatures against Mindszenty prepared his show trial in 1948. The Hungarian communist comic paper tried to influence the mood of the readers against the archbishop, attempting to convince them that he supported Hungarian fascists. The beginning of the trials of Mindszety (1948) and Stepinac (1946) explains that the number of anticlerical caricatures in Jež is much higher in the analysed period. ${ }^{20}$

\section{Perceptions of democracy and the Western states}

The negative evaluation of the church and of religious ideas is very similar to the negative opinion about democracy and Western states. The church and religious ideas as well as democracy and Western states were seen as enemies of communism, which explains the negative evaluation in these topics in the caricatures. Firstly, Great Britain and the United States of America symbolised Western democratic ideas and capitalism contrary to the "true" democracies, people's democracies. These two countries were depicted in a negative manner in the caricatures as supporters of the right wing governments and continuing to support right wing politics after WWII as well. According to the comic papers, Uncle Sam (the personification of the US) and John Bull (the personification of Great Britain) observe in their zones of occupied Germany how the Nazis propagate their ideas

\footnotetext{
${ }^{17}$ e.g. Ludas Matyi, 3 February 1946.

${ }^{18} J e \check{z}, 9$ February 1946.

${ }^{19} J e z ̌, 14$ September 1946.

${ }^{20}$ One can observe more anticlerical caricatures in Ludas Matyi from 1948. See Kovács 2013: 455.
} 
instead of calling on the Nazis to account for their sins, therefore the loudly announced denazification is only propaganda and not reality. Moreover, in one caricature Uncle Sam gives money and gifts to the Nazis and in another he gives it to the personification of Germany, Germania, who is wearing Nazi symbols, while the other Western European countries stand in a line disappointedly, waiting for a present, too. It suggested the lack of success of the denazification as well that, according to Hungarian and Yugoslav caricatures, Hitler's Mein Kampf is a favourite reading or even a "Bible" in Germany. In other representations small children - either as SS-soldiers or well-known SS-soldiers as innocent children-are playing games peacefully. The depiction of children mocked the false innocence of the Nazis. In one caricature in Jež one can see SS-soldiers playing games in a kindergarten. One of them has a skirt on and a whip in his hand, the other one plays ball with a skull, and the third one is holding a balloon-like bomb over the concentration camp of Dachau. According to the caption, Americans perceive "innocent SS-soldiers" in their zone like this. In Ludas Matyi one can see Hungarian fascists as small children playing with toy trains and tin soldiers. ${ }^{21}$ In contrast, as mentioned above, Ludas Matyi and Jež often emphasized that the countries with communist — or partly communist—leadership punished war criminals strictly, that the scales of values of people's democracies were higher, and they were not afraid of punishing their enemies.

The communist comic papers propagated not only that the US and Great Britain observe the actions of the Nazis in Germany, but also that they support extreme right wing regimes in Europe after WWII. First, the Spanish dictator Francisco Franco (in office: 19391975) appeared in Jež in this role: he had received money from one of the Western powers, which ignored how many gallows and murdered people can be seen next to him. The gallows and skulls are present in the caricatures almost like visual "epitheton ornans", while the dictator can be often observed standing on skulls or bones next to the gallows. ${ }^{22}$ Ludas Matyi depicted the dictator as well, but not so radically, for example as a mad bull- because of his nationality. ${ }^{23}$ Jež accuses Franco of "concealing fascists and guilty clerics under his cloak", and Uj Szó depicted him in the same context suggesting that Franco had close connections with Nazis and was supported by the Spanish Catholic Church, too. ${ }^{24}$ Jež accentuated also that it was not only the Croatian Catholic Church that took part in crimes against humanity, but also the Spanish one, supporting Franco's regime (e.g. Fig. 3). In spite of the fact that Spain was neutral in World War II, Franco appeared in Jež through the same symbols as Stalin in the German and Hungarian comic papers during WWII. During WWII the Soviet dictator was depicted as inflicting unbounded violence, amidst bones and skulls, and enjoying killing, like Franco in Jež. ${ }^{25}$ The tools of propaganda against the enemy were very similar independent of the ideological background or the state in which the comic paper appeared.

The other group appearing often in $J e \check{z}$ as fascist were the Greek right wing monarchist soldiers, fighting against the Greek communists during and after WWII. The

\footnotetext{
${ }^{21}$ Jež, 18 May 1946, Jež, 9 August 1947, Jež, 12 April 1947, Ludas Matyi, 14 June 1945.

${ }^{22}$ Jež, 2 March 1946, Jež, 20 April 1946.

${ }^{23}$ Ludas Matyi, 28 April 1946.

${ }^{24} \mathrm{Jež}, 9$ March 1946, Új Szó, 27 April 1946.

${ }^{25}$ Tamás 2015: 115.
} 
Serbian comic paper was much more interested in foreign policy first, because Yugoslavia supported the Communist Party and its military force in the Greek Civil War (1943-1949), but Hungary did not participate in foreign affairs so actively. ${ }^{26}$ Jež mocked the anticommunist forces, the Greek Monarcho-fascist regime, democracy itself, and it represented the anti-communist Greeks and the Western states - helping Greece - as fascists. The same caricature was published - with small differences - both in Jež and Ludas Matyi: it depicts two Greek soldiers writing the sentence "Long live fascism!" on a black board, but they have orthographical problems. In the Hungarian version, the Greek person cannot decide how many s's the word "fascism" should be spelled with, whereas in the Serbian version the soldier does not know how to spell the same word correctly. The other person in the caricature encourages him to write "Long live Western democracy!" instead in both comic papers. ${ }^{27}$ According to the message of the caricatures, democracy and fascism are identical systems and scales of values, therefore they are interchangeable and not only on the black board. The situation is different in the "true" democracies, the people's democracies, which was the aim of the communist parties. The pictures in connection with the Greek Civil War suggest that the financial support and the weapon cargos of John Bull and Uncle Sam are not selfless help but serve the expansion of Western political and financial power, and this neo-fascist scale of values remains in contrast with the Yugoslav and Hungarian aims and values.

The judgement of the Western states changed in the same direction in the two communist comic papers. The evaluation of Great Britain changed radically after Churchill's Iron Curtain Speech on 5 March 1946 in Fulton, but the image of the US, which wanted to expand capitalism and democracy - even forcefully — was much more unfriendly in the analysed comic papers. To summarize the opinion of the caricaturists, I can mention the following cartoon in which Churchill is sitting on the throne of the "Western Bloc" and one can also see the world under his throne: there are atomic bombs, Nazis, Ustaša and Chetnik soldiers, African-Americans, dead people, skulls, and graves ${ }^{28}$ not suggesting a safe and happy Western world. Nevertheless, one of the most frequent topics was the Marshall Plan, the financial aid of the US which the Secretary of State Georges Marshall drafted on 5 June 1947. From this time the Hungarian comic papers showed more activity in the field of foreign politics, too. The states of the Soviet Bloc declined the Marshall Plan, therefore, Ludas Matyi had to propagate against it and against the US as well. The first mention of the Marshall Plan was a caricature with the title "The 'munitions' of General Marshall" in the Yugoslav comic paper showing the context of the financial aid in later caricatures as well: Marshall is holding atomic bombs with dollar signs and with captions ("financial aid", "homeland security") on them suggesting a new destructive atomic war. ${ }^{29}$ After WWII people were exhausted and afraid of an atomic war, therefore it was an effective propaganda tool to state that the Western European states and the US would spark a new

\footnotetext{
${ }^{26}$ Hungary supported Greek refugees, too. The country was not in the situation to take part militarily - the Soviet Red Army was in Hungary and Stalin gave up having Greece in the Soviet Bloc (1944)—or financially in foreign affairs actively. (Balogh 2013: 91-97.)

${ }^{27}$ Jež, 21 March 1947, Ludas Matyi, 15 February 1947.

${ }^{28} \mathrm{Jež,} 18$ May 1946.

${ }^{29}$ Jež, 22 March 1947.
} 
war. According to $U_{j}$ Szó, the US was raising a child, a new Hitler for Europe and fed him with the Marshall Plan. ${ }^{30}$ Moreover, the communist caricatures suggest that European countries have to obey Uncle Sam in exchange for his money and he is acting like an oppressor and does not like a fair loaner. A caricature with the title "Mr. Dollar is not guilty" published in 1947 summarizes the charges against the US. The US appears as an ugly monster who destroyed the world around him, he holds a gun is his hand, blood dripping from his fingers. Next to his feet are skulls and bones, on his cylinder is a dollar mark. According to the caption, the US did not declare itself to be guilty of the destruction, thus its personification does not take responsibility for his acts but tries to shift his responsibility, which shows that his intentions are not truthful. ${ }^{31}$ Money and (atomic) weapons became "epitheton ornans" of the US in the communist caricatures. According to the caricatures the aims and methods of the US were cruel, which was propagated forcefully and systematically from the beginning in the communist press. Both of the communist comic papers recall as a proof of its cruelty that the US exterminated Indians in a hundred years and now is planning do the same with the communists - using a pun with the word "red" which was used for both groups. The pun is identical in the caricatures, but the visual appearance is different. In Ludas Matyi president Harry Truman corrects the following sentence: "The right of Reds to living and freedom is inalienable." In his new version these rights are "alienable", however, Truman assures the Indians in the corner of the caricature that in this case he is referring to the communists (who are not depicted) and not to them. ${ }^{32}$ In the Jež version of the caricature Uncle Sam is aiming a pistol first at the Indians and then looks at workers distrustfully. ${ }^{33}$ The Yugoslav comic paper keeps reminding its readers also that in America Blacks do not have rights and the Ku Klux Klan is flourishing. ${ }^{34}$ Moreover, America appeared not only as an evil capitalist country on the straight road to fascism but also as a bad ally betraying his nearest associate, John Bull, thus sending the message to the Eastern European states that they will be betrayed as well if they take the financial aid of the US, the Marshall Plan. In Ludas Matyi a caricature appeared with the title "Fire in London" and John Bull has to jump out of the burning tower of the Big Ben. Uncle Sam reassures the British with the following sentence: "You just have to jump, everything else is our job." The Americans hold only a flag with a hole, thus it is not sure that John Bull can survive this jump. ${ }^{35}$ The Jež adopted the Hungarian caricature, but they changed the title for "Help!" and the caption for "Please, save yourself!" 36 In Jež Uncle Sam seems to have been crueler than in Ludas Matyi. Uncharacteristically of Hungarian caricatures, Jež propagated that certain states (for example Spain) got financial aid whereas in fact they did not. ${ }^{37}$ However, it did not mention that Yugoslavia got not only war reparations but also UNRRA aid (which existed before the Marshall Plan). In the caricatures the acceptance of financial

\footnotetext{
${ }^{30}$ Új Szó, 3 August 1947.

${ }^{31}$ Jež, 18 October 1947.

${ }^{32}$ Ludas Matyi, 30 April 1947.

${ }^{33}$ Jež, 28 June 1947.

${ }^{34}$ Jež, 14 June 1947.

${ }^{35}$ Ludas Matyi, 14 May 1947.

${ }^{36}$ Jež, 28 May 1947.

${ }^{37}$ e.g. Jež, 22 November 1947.
} 
aid appeared as a sin and a country which used financial support became a new Nazi state like the US.

\section{Democrats and German enemies within the country}

In contrast with Jež, Ludas Matyi attacked the democratic parties in Hungary rather than seek international topics to focus on, and its caricaturists turned the members of these parties into Nazis or fascists through similar visual tools as in the case of foreign enemies. Doctors in a caricature in the Ludas Matyi are taking an X-ray of a man representing Hungarian democrats. The result of the test is that although he says he is a democrat, one can observe an arrow cross in place of his heart, his facial features are similar to Hitler's and further names of extreme right wing organisations and their symbols (e.g. a swastika) can be seen in his X-ray. ${ }^{38}$ Therefore, according to the propaganda caricature Hungarian democrats are not "true" democrats; communists represent a "true" democracy, the people's democracy, thus other democrats are enemies.

A characteristic feature of the Hungarian communist comic paper is that the Germans living in Hungary ("Swabians") were depicted as collective war criminals who deserved their relocation back to Germany ${ }^{39}$ according to the caricatures. The depiction and logic of the caricatures are similar to the visual representation of the Nazis. The person representing Swabians can be seen with his German (national) attributes from the $19^{\text {th }}$ century, wearing a nightcap and slippers. In a caricature he sees the pictures of the members of Szálasi's fascist government hanging on his wall. Szálasi is in the middle, drawn a little like Hitler (the Hungarian leader did not look like Hitler). The Hungarian politicians of Swabian origin were also depicted so that they were admirers of the Hungarian fascists or German Nazis, and they appeared with an arrow cross on their clothes. Swabians were also represented as the killers of Hungarians, because in one caricature a Swabian murders Hungarians who arrived through the population exchange agreement (signed in 1946 with Czechoslovakia). In the last caricature, in which German families appeared waiting by a train, one person is coming out of a building complaining that he barely had enough time to shoot the chairman of the relocation committee. Today's audience would associate these people's luggage with the inhuman circumstances of the relocations; however, the aim of the caricaturist was exactly the opposite: the caricaturist wanted to confirm the cruelty of Swabians - the German man's gun is smoking, he pulled the trigger-legitimizing the relocations and doubting their complaints that they did not have enough time to pack their valuables (and they do not deserve more time) ${ }^{40}$ The German inhabitants of Yugoslavia occupied during World War II do not appear in the comic paper as collaborators, in fact, the German minority of Yugoslavia did not appear in the Yugoslav paper's caricatures at all, because most of the German minority of Yugoslavia was persecuted and relocated before the end of WWII (1944) ${ }^{41}$

\footnotetext{
${ }^{38}$ Ludas Matyi, 5 May 1946.

${ }^{39}$ About the relocations see Seewann 2012: 342-375.

${ }^{40}$ Ludas Matyi, 1 July 1945, Ludas Matyi, 28 February 1947, Ludas Matyi, 23 July 1947.

${ }^{41}$ Ramet 2011: 225.
} 


\section{Depiction of the self}

The communist image of the hard working peasants and industrial workers appeared also in the comic papers and in this topic the caricaturists used the oppositions as a visual tool often so they contrasted the two, the communist and democratic scales of values in caricatures. ${ }^{42}$ On the one hand, one can observe workers (rarely peasants) working, building or celebrating happily. ${ }^{43}$ I have to note that physical work was a major element of communist propaganda, too. On the other hand, the Western states or the pre-WWII regimes knew only the destruction, at least according to the communist comic papers. In all of these kinds of depictions one can see the contrast of building and destroying something - directly or metaphorically. The people's democracies were built after WWII symbolically as well: they were building a new world, a world very different from the capitalist one, in which they would work hard and live happily (Fig. 4). ${ }^{44}$

In the analysed period the caricatures about the positive worker image are not frequent in the Hungarian comic papers. One can observe happy workers during the celebration of the anniversary of the liberation of the country (4 April 1945) by the Soviet Red Army. In these pictures the motif of destruction appeared as well, as did the necessity for the help of the Soviet Red Army ${ }^{45}$ However, the assistance of the Soviet Army is absent from the Yugoslav comic paper in spite of the fact that the partisans were also supported by the Soviet Red Army. It is characteristic of the representation of workers in the Hungarian comic papers that they appear like the traditional symbol of the Communist Party (as a strong man with a red hammer) in a socialist realist style with long traditions from the beginning of the $20^{\text {th }}$ century. However, this way of depiction of workers is missing from $J e \check{z}$ and the figures of this comic paper are closer to "average" human beings.

\section{The battle of Pax and Mars}

Lastly, I would like to mention the depiction of the Peace Treaty of Paris, which was signed late, in February 1947, almost two years after the military events of WWII ended in Europe, when the new front lines of the Cold War seemed to finalize. In Ludas Matyi the angel of peace bandages the wounds of the Earth before the signing of the peace treaty. In another caricature Pax beats Mars, the Roman god of war, but her dress is torn and she has many scrapes and bruises, which she is looking at in her hand mirror, deciding to put on makeup (Fig. 5). Also, before the signing of the peace treaty a caricature appeared, in which nations - Romania, Hungary, the Soviet Union, Yugoslavia, Bulgaria, Finland, Italy, the US, and Austria - serenade under the balcony of Pax showing the wish to have peace on Earth. However, a diplomat pulls back Pax, because his aim is to hinder the signing of the treaty.

\footnotetext{
${ }^{42}$ The depiction of communists or Bolsheviks was different before and during WWII. The communists - who were persecuted - were represented as evil Jews aiming at power or as Anarchists destroying the Western world and values. They appeared for example as devils or Death, they had Jewish features in the caricatures which could evoke negative associations itself.

${ }^{43}$ E.g. Fig. 4, Pesti Izé, 19 January 1947.

${ }^{44}$ Jež, 12 January 1946, Jež, 9 February 1946, Jež, 2 August 1947.

${ }^{45}$ Pesti Izé, 6 April 1947.
} 
In this caricature the diplomat does not belong to any nation, one cannot recognize him, but in other depictions America is blamed for sabotaging the signing of the peace treaty. ${ }^{46} \mathrm{In}$ the last issue of Ludas Matyi in 1947 the countries of the Eastern Bloc are dancing around the Christmas tree, the children - symbolizing nations - are happy, their mother is Pax, who wears a five-pointed star as a decoration in her hair. The new people's democracies can be successful, they are innocent children, not being responsible for the sins of their parents. ${ }^{47}$ The British and American children do not want to participate in the dance circle because they have to put down their toys - a battle-ship and an atomic bomb-to hold the hands of the other children. Eastern European children look similar in the caricature, their national attributes are visible, but they are not emphasized any more, which is a difference from the caricatures from before WWII. Ludas Matyi suggests that "the Other" will not be an ethnic group in the near future, but otherness will be defined through ideology: communists are friends, while all others are enemies.

\section{Conclusions}

I can conclude that one common feature of the above mentioned propaganda caricatures - following the political events closely - is that they announced forcefully the beliefs of the new communist governments or Communist Parties. They called the war criminals to account for their sins - in caricatures as well-but only a few prominent leaders, and the communist press blamed also persons who were not guilty. The beginning of a new age, the development of the Cold War can be documented well in the caricatures in Jež and Ludas Matyi. Both in the Hungarian and Yugoslav comic paper depictions appeared suggesting Europe was divided in two parts, East and West at the end of the analysed period. The problem of one Europe or a divided Earth in two parts arose basically as a question that would be decided in the near future. One can observe in the middle of the divided globe Mars, the god of war, suggesting the consequences of the Cold War. ${ }^{48}$ For the new, destructive atomic war the Western capitalist democratic powers would be responsible. Thus, they did not differ from the war criminals of the extreme right groups as they would cause much more suffering.

Comic papers attempted to achieve the deheroisation of the heroes of the past (for example, Draža Mihailović) in order to reduce the loyalty of the readers to the former political system and to present new heroes (e.g. the leader of the Communist Party in Hungary, Mátyás Rákosi or the workers themselves). The distorted depiction of the former leaders (Horthy, Mindszenty, Stepinac etc.) served this aim as well, like the representation of Western countries and different domestic groups or clergy as enemies, or the depiction of other groups (like the communists or workers) in a one sidedly positive way.

\footnotetext{
${ }^{46}$ Ludas Matyi, 27 May 1945, Ludas Matyi, 28 April 1946.

${ }^{47}$ Ludas Matyi, 24 December 1947.

${ }^{48}$ Ludas Matyi, 19 November 1947.
} 


\section{Acknowledgements}

The research presented in this paper was funded by the Hungarian Scientific Research Fund, OTKA, grant PD 109069. I would like to thank Péter Heinermann for his help in the Matica Srpska Library in Novi Sad and Arnold Szőcs for the translation of Serbian captions.

\section{REFERENCES:}

Balogh, Á. Fejezetek Görögország újkori történetéböl ('Chapters of the history of the modern Greece'), Szeged: Magyarországi Görögök Kulturális Egyesület Csongrád Megyei Helyi Csoport, 2013.

Horváth, A. A magyar sajtó története a szovjet típusú diktatúra idején, ('History of the Hungarian press during the Soviet type dictatorship') Budapest: Médiatudományi Intézet, 2013.

Kaelble, H. Der historische Vergleich, ('The historical comparison') Frankfurt am Main: Campus Verlag, 1999.

Kovács, K. 'Reakczy Jóskától Kulák Kelemenig. Válogatás a Ludas Matyi 1945 és 1949 közötti bünbak-karikatúráiból' ('From Reakczy Jóska to Kulák Kelemen. A selection of scapegoat caricatures in Ludas Matyi from 1945 to 1949'), in: Gy. Gyarmati and I. Lengvári and A. Pók and J. Vonyó (eds.), Bünbak minden idöben. Bünbakok a magyar és az egyetemes történelemben, ('A scapegoat at all times: Scapegoats in Hungarian and world history') Pécs/Budapest: Kronosz-MTT-ÁBTL, 2013, 444-455.

Ramet, S. P. Die drei Jugoslawien. Eine Geschichte der Staatsbildungen und ihrer Probleme, ('The three Yugoslavias: The history of state building and its problems') München: R. Oldenbourg Verlag, 2011.

Seewann, G. Geschichte der Deutschen in Ungarn, ('The history of Germans in Hungary). Vol. 2. Marburg: Verlag Herder Institut, 2012.

Tamás, Á. 'The faces of the enemy in the two World Wars: A comparative analysis of German and Hungarian caricatures', in: D. Demski and L. Laineste and K. Baraniecka-Olszewska (eds.), War matters: Constructing images of the other (1930s to 1950s), Budapest: L'Harmattan, 2015, $108-127$. 


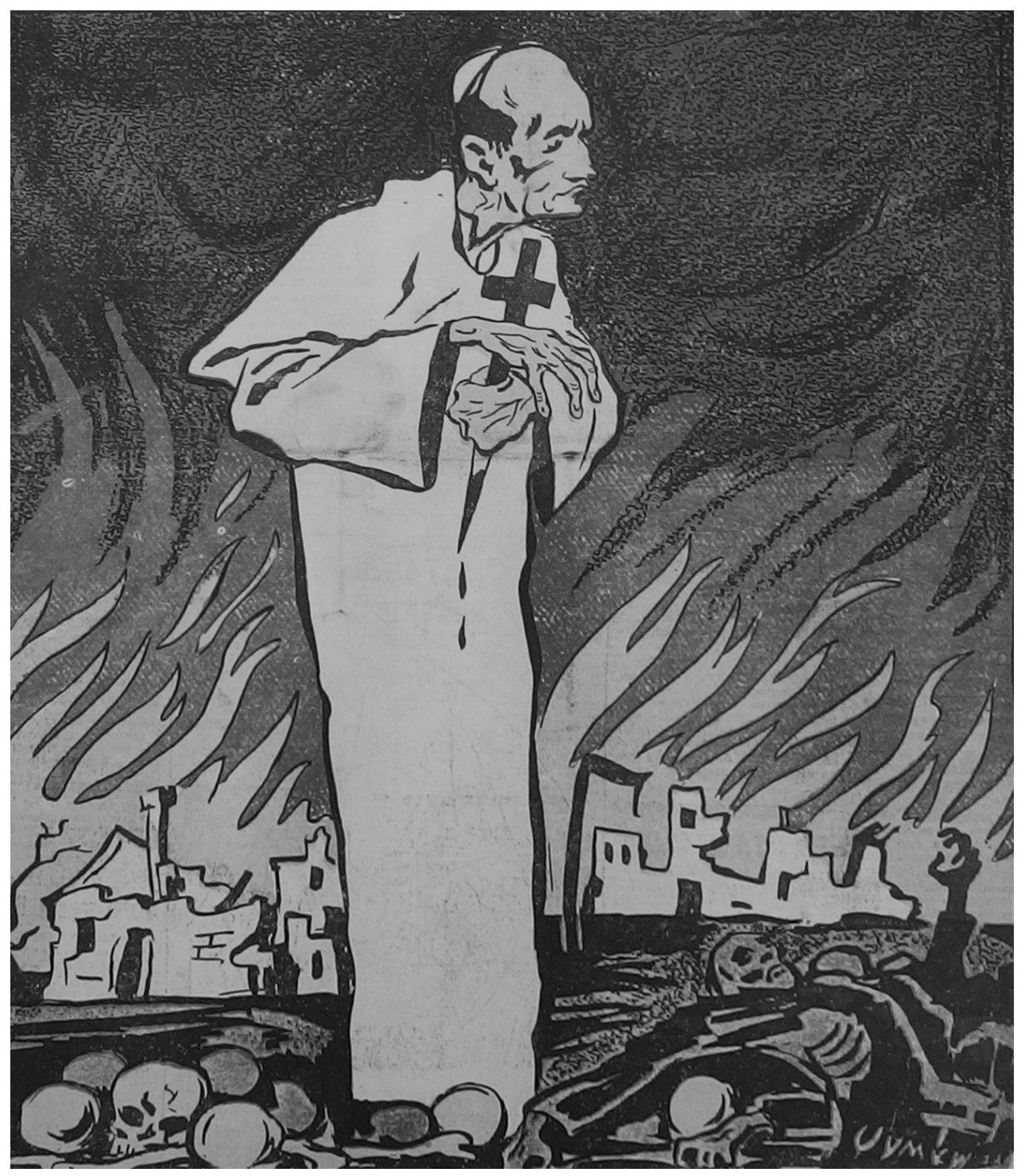

Fig. 1

We stay perfectly calm.

Our conscience is clear; we do not have anything to hide.

Jež, 12 October 1946. 


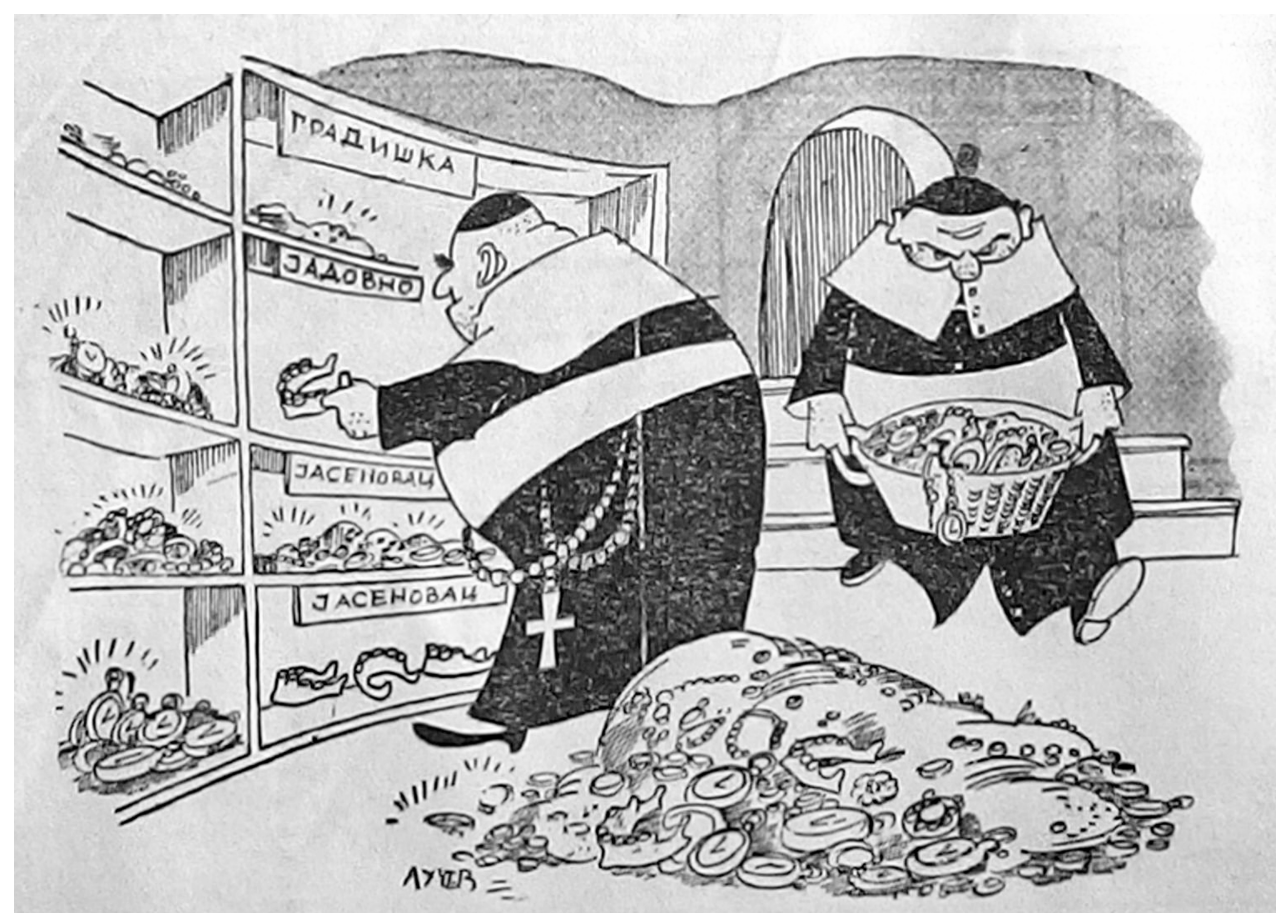

Fig. 2

The archives of the cathedral

I always loved archiving activities.

Jež, 2 March 1946. 


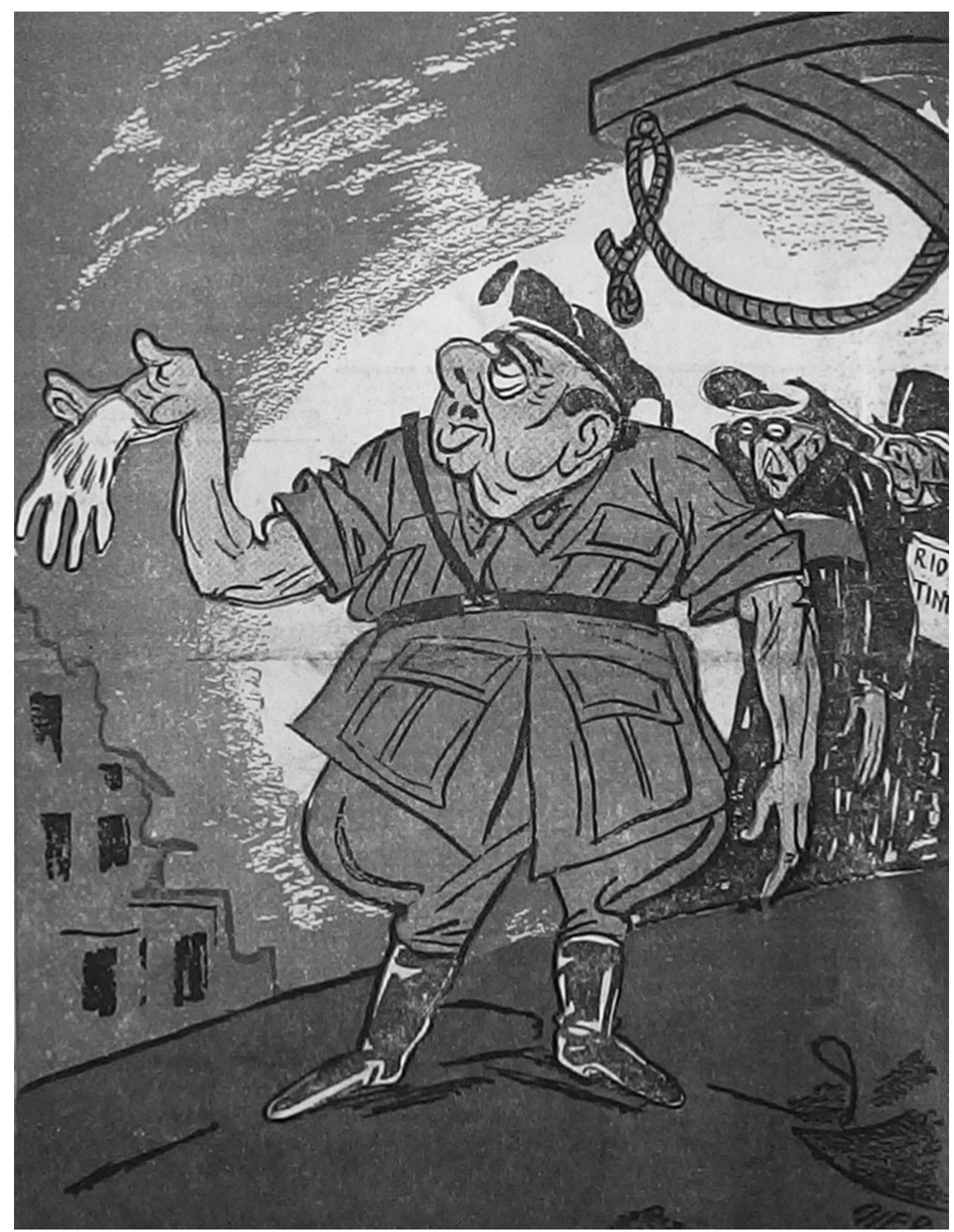

Fig. 3

The innocent executioner

I am not responsible for the death of these people, but those are who allow me to do this. Jež, 2 March 1946. 


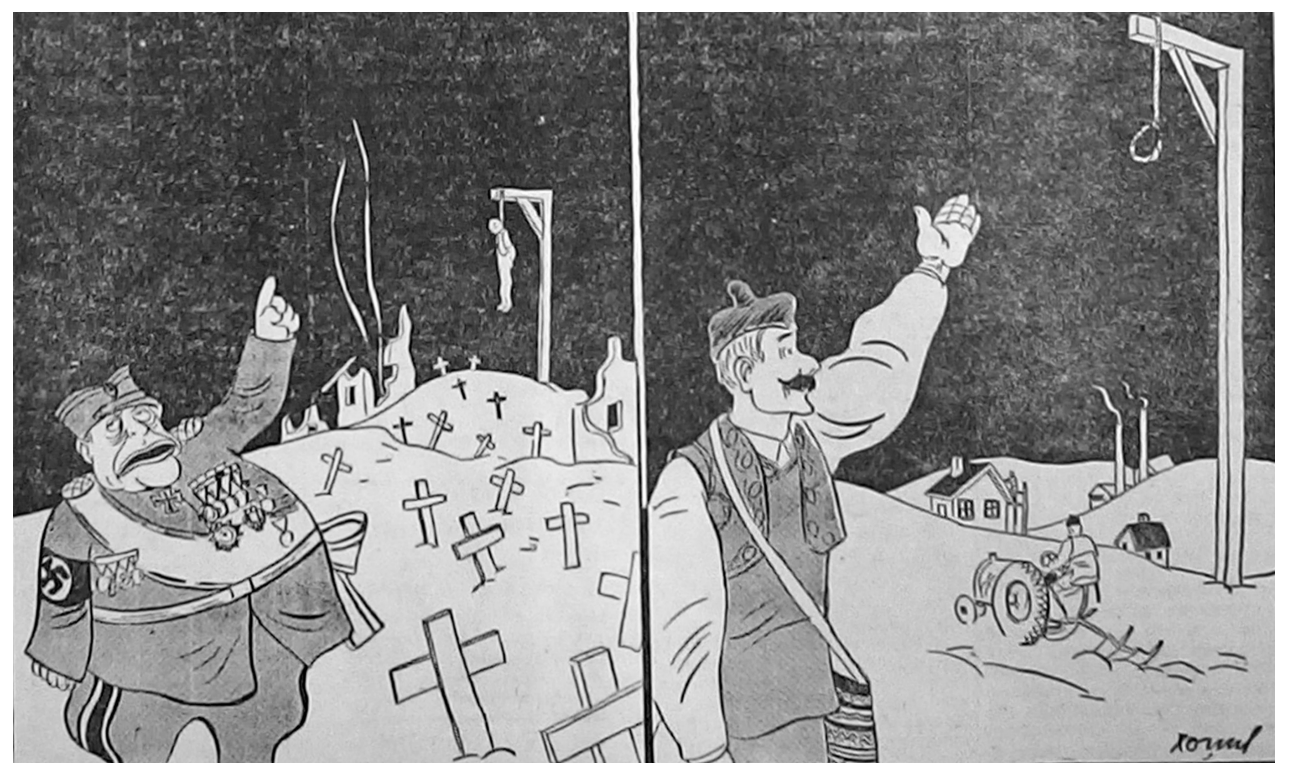

Fig. 4

Then and now

Milan Nedić: Serbia above all!

Serbian people: Over Serbia!

Jež, 12 January 1946. 


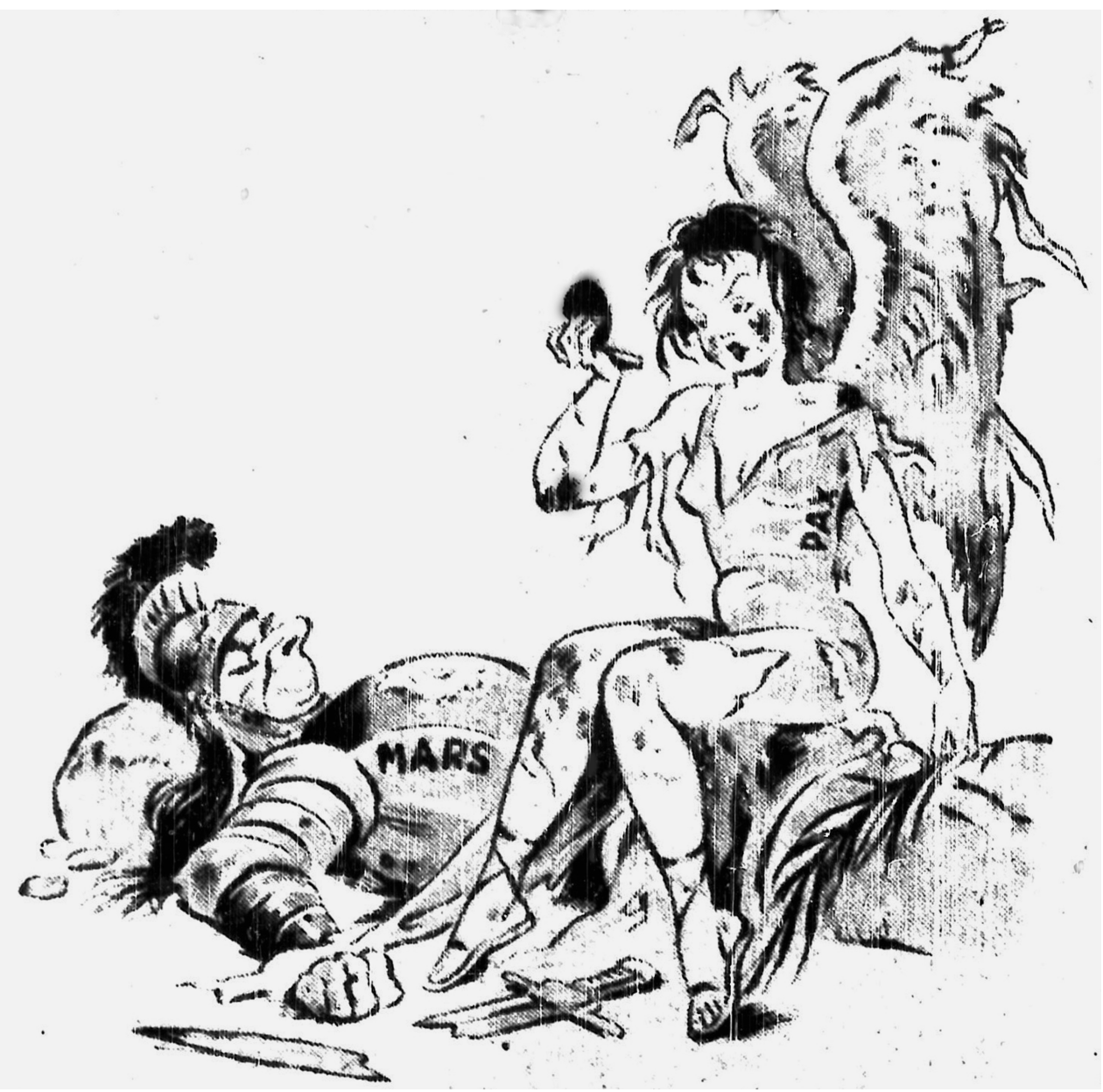

Fig. 5

The situation of the world

Pax: Finally! I won! ... But now I have to put on makeup.

Ludas Matyi, 23 December 1945. 


\section{АГНЕШ ТОМАШ \\ Универзитет у Сегедину, Одсек за модерну историју Мађарске \\ СТАРИ И НОВИ НЕПРИЈАТЕЉИ У КАРИКАТУРАМА У ПРВИМ ГОДИНАМА НАКОН ДРУГОГ СВЕТСКОГ РАТА (1945-1947)}

\section{Резиме}

Други светски рат је завршио пре 70 година а Париска мировна конференција је одржана 1947. године, где је потписан споразум са пораженим земљама источне Европе. У раду анализирамо карикатуре из овог периода из мађарских и југословенских стрипова (Ludas Matyi, Pesti Izé, Jeж, и Új Szó). Ово је у Мађарској био период парламентаног плуралитета а након ових година на власт су постепено дошле комунистичке партије. У Југославији су оне већ биле на власти. Овај кратак период је био слободнији него строго цензурисан период током Другог светског рата, али и слободнији од комунистичког доба. У Мађарској се појавило више нових стрипова, који су одражавали ставове различитих (ре)организованих партија. У раду користимо метод историјске компарације X. Келбла да бисмо открили следеће: прво, анализирамо како се приказују фашисти на крају и после рата у различитим земљама. У Мађарској се фашисти појављују као „нови непријатељи,“ зли „Други“ након завршетка цензуре десно оријентисаних влада. Ко је био одговоран за рат и страдања након рата у карикатурама? Комунисти (Бољшевици) су били „стари непријатељи“ и они су били забрањивани и прогањани у ових земљама. Како се променило приказивање комуниста у овом периоду у различитим земљама? Да ли је било слично приказивању Бољшевика пре и током Другог светског рата? Да ли су карикатуристи створили нове комунистичке фигуре током послератног периода? Да ли су стрипови поражених земаља такође приказивали победнике као зле „Друге“? (После Првог светског рата земље победнице су се нпр. приказивале као ђаволи, итд.) Напослетку, како су карикатуре приказивале Париску мировну конференцију?

Анализиране карикатуре су осуђивале ратне криминалце, али комунистички стрипови су такође стварали нове непријатеље као што су западне демократске идеје, западне државе, свештенство, итд. С друге стране, у Источном блоку пропаганда је обећавала светлу будућност.

Кључне речи: Карикатуре, мађарски и југословенски сатирични листови, приказивање непријатеља, пропаганда. 